Original Article

\title{
SHELF-LIFE ASSESSMENT OF EUPHORBIA ANTIQUORUM LINN., EUPHORBIA CADUCIFOLIA HAINES, EUPHORBIA NIVULIA BUCH. HAM AND EUPHORBIA TIRUCALLI LINN. LATEX
}

\author{
SUDIPTA ROY ${ }^{\text {, RABINARAYAN ACHARYA2*, ANAGHA RANADE }}{ }^{3}$, M. S. CHOLERA ${ }^{4}$
}

${ }^{1}$ SRF, NMPB Project, ${ }^{2}$ Dravyaguna, IPGT and RA, Gujarat Ayurved University, Jamnagar, ${ }^{3}$ RAIFR, CCRAS Unit, Pune, ${ }^{4}$ Head, Microbiology laboratory, IPGT and RA, Gujarat Ayurved University, Jamnagar

Email: drrnacharya@gmail.com

Received: 20 Aug 2019, Revised and Accepted: 26 Dec 2019

\section{ABSTRACT}

Objective: In the present study, an attempt was made to assess the shelf life of the Snuhi latex which is frequently used in fresh condition for the preparation of Ksharasutra, a medicated thread, used in Ayurveda.

Methods: The latex of E. antiquorum, E. caducifolia, E. nivulia and E. tirucalli were collected individually and stored in air tight glass vials during the month of May, 2018. Physical attributes like Colour, odour, appearances, $\mathrm{pH}$ and microbial load of all four samples were assessed as per standard protocol. Assessment was made every day, $9 \mathrm{AM}$, for $7 \mathrm{~d}$ in room temperature and for $10 \mathrm{~d}$ in refrigerated samples.

Results: Result shows that, $\mathrm{pH}$ range (start-end day) was 4.25-5.18, 4.79-5.12, 4.48-4.76 and 4.40-5.42 in case of E. antiquorum, E. caducifolia, E. nivulia and E. tirucalli at room temperature. It was found that, Aspergillus niger was found in Euphorbia antiquorum, Euphorbia caducifolia whereas Candida albicans was found in Euphorbia tirucalli latex in fungal culture on the $7^{\text {th }}$ day after collection, when the samples were stored at room temperature. All the samples were free from microbial growth up to $10^{\text {th }}$ day when stored at $4-5^{\circ} \mathrm{C}$ in a refrigerator.

Conclusion: Temperature, and moisture affects the quality of fresh snuhi latex. The latex remains free from microbial growth up to six days in room temperature and up to $10 \mathrm{~d}$ under at refrigerated temperature $\left(4-5{ }^{\circ} \mathrm{C}\right)$.

Keywords: Snuhi, Stability, Shelf-life, Euphorbia, Ksharasutra

(C) 2020 The Authors. Published by Innovare Academic Sciences Pvt Ltd. This is an open access article under the CC BY license (http://creativecommons.org/licenses/by/4.0/) DOI: http://dx.doi.org/10.22159/ijpps.2020v12i2.35406. Journal homepage: https://innovareacademics.in/journals/index.php/ijpps

\section{INTRODUCTION}

Ayurveda emphasizes on standardization of the drugs starting from its cultivation and collection. Various standards, in this regard, have been laid down in the classical texts of Ayurveda. It has been reported that both organized and unorganized part of plants should be collected on certain seasons to get their better yield and therapeutic value. Latex (Kșhira) is one of such unorganized part of plant which has been delineated for its therapeutic value. Snuhi is one of the latex bearing plants which has been quoted in management of different diseases like Gulma (tumor), Kustha (leucoderma), udara (ascities) etc. Currently, this latex finds an extensive use in preparation of Ksharasutra which is used clinically in treating anal fistulas [1].

According to the different text the botanical sources of different types of Snuhi have been reported such as Euphorbia antiquorum (Tridhara snuhi, Vajrakantaka), Euphorbia caducifolia (Rakta snuhi) and Euphorbia tirucalli (Kanda snuhi). All the plants belong to the family Euphorbiaceae [2,3]. Most of the members of the family Euphorbiaceae are the latex bearing plants. Latex is a milky fluid with a complex mixture of proteins, vitamins, carbohydrates, lipids, terpenes, alkaloid and free amino acids. The presence of certain enzymes like chitinase and protease in latex vacuoles suggests that they may help plants for defense against pathogens [4]. Availability of these plants as per geographical variations, the time consuming process of latex collection and its clotting property makes the assessment of shelf-life of these latex samples demanding.

Shelf-life is an important attribute to assess the safety, quality and stability of any single or compound drugs. It is defined as the time during which the product will remain safe, retain desire sensory, chemical, physical and microbiological characteristics, comply with any label declaration of nutritional data and will be acceptable to the uses. Shelf-life testing is necessary to determine the stability of a sample for its uses. Stability testing mainly of five types, i.e. physical, chemical, microbiological, therapeutic and toxicological [5-7].
Latex of Snuhi has an important place in different therapeutic formulations, but the stability or self-life of the latex has not been reported yet. Hence, the present study was designed to evaluate the shelf-life of latex sample of four varieties of Snuhi i. e Euphorbia antiquorum Linn., Euphorbia caducifolia Haines., Euphorbia nivulia Buch. Ham. and Euphorbia tirucalli Linn.

\section{MATERIALS AND METHODS}

Identification and authentification of plants

Four species of Snuhi growing naturally in abundance in the peripheral areas of Jamnagar, Gujarat, were identified by local taxonomist and their respective botanical name, i.e. Euphorbia antiquorum Linn, Euphorbia caducifolia Haines, Euphorbia nivulia Buch.-Ham and Euphorbia tirucalli Linn were confirmed by studying the morphological characters, of various parts and comparing them with various characters described in different floras and books [8]. Colour photographs were taken during different seasons and wet specimen of each sample was prepared following standard guidelines. For authentication and preservation, fresh twig of each plant species along with inflorescence was stored in AAF (70\% Ethyl alcohol: Glacial acetic acid: Formalin) solution in the ratio of 90:5:5 for further study [9]. Sample specimens were authenticated by an expert of Pharmacognosy laboratory of Gujarat Ayurved University, Jamnagar and wet specimen of each sample has been deposited in the institute's Pharmacognosy museum for the further referencing. The specimen numbers are PHM/2015-2016/6269, PHM/2015-2016/6213, PHM/2015-2016/6270 and PHM/2015-2016/6268 of Euphorbia antiquorum Linn, Euphorbia caducifolia Haines, Euphorbia nivulia Buch.Ham and Euphorbia tirucalli Linn., respectively.

\section{Chemical and reagents}

Ethanol was procured from Rankem, Mumbai, Potassium hydroxide, Gram's Iodine solution, Sabouraud Dextrose Agar Base (SDA), Modified Dextrose Agar Base, Emmons, MacConkey Agar (MA) and Columbia Blood agar (BA) were procured from HIMEDIA Laboratories Pvt. Ltd. And all are of laboratory grade. 


\section{Collection of sample}

The fresh crude latex of E. antiquorum, E. caducifolia, E. nivulia and $E$. tirucalli were individually collected from the stem after cleaning with Ethanol, by incision method in clean glass vials at morning time. The study was conducted at Microbiology Laboratory, IPGT and RA, Jamnagar, India.

\section{Storage}

A latex sample of each plant was equally divided into two airtight clean glass vial and one vial kept at room temperature in a dark, dry place and another sample was kept in the refrigerator. Stability was assessed for $7 \mathrm{~d}$ in the case of sample stored at room temperature and for $10 \mathrm{~d}$ in case of refrigerated samples (table 1).

Table 1: Storage condition of samples

\begin{tabular}{lrll}
\hline Days & Temperature & Relative humidity & Date \\
\hline \multicolumn{2}{l}{ Room temperature condition } & & $1 / 5 / 18$ \\
1 & $31{ }^{\circ} \mathrm{C}$ & $62 \%$ & $2 / 5 / 18$ \\
2 & $30^{\circ} \mathrm{C}$ & $46 \%$ & $3 / 5 / 18$ \\
3 & $31{ }^{\circ} \mathrm{C}$ & $56 \%$ & $4 / 5 / 18$ \\
4 & $32^{\circ} \mathrm{C}$ & $52 \%$ & $5 / 5 / 18$ \\
5 & $30^{\circ} \mathrm{C}$ & $31 \%$ & $6 / 5 / 18$ \\
6 & $33^{\circ} \mathrm{C}$ & $27 \%$ & $7 / 5 / 18$ \\
7 & $31{ }^{\circ} \mathrm{C}$ & $51 \%$ & $1 / 5 / 18-11 / 5 / 18$ \\
\multicolumn{2}{l}{ Refrigerated condition } & & \\
$1-10$ & $4-5{ }^{\circ} \mathrm{C}$ & $70-80 \%$ & \\
\hline
\end{tabular}

\section{Sampling}

Samples were subjected for short-shelf-life product testing up to $1 \mathrm{w}$ to $10 \mathrm{~d}$ and sample was taken off daily for evaluation. Details of which are cited below [6].

\section{Physical measurements}

Colour, odour, appearances and $\mathrm{pH}$ of all four samples was assessed daily after $24 \mathrm{~h}$ at the same time of every day for $7 \mathrm{~d}$ in the case of sample stored at room temperature and for $10 \mathrm{~d}$ in case of refrigerated samples.

\section{Microbiological measurements}

Microbial contamination was assessed by two methods to check any Mycological findings and Bacteriological findings. One was Smear Examination which included 10\% Potassium hydroxide (KOH) Preparation and Gram's stain whereas another one was Culture Study which included fungal culture and Aerobic culture. The details of the procedures followed has been given below.

\section{Smear examination}

\section{$10 \%$ potassium hydroxide K. O. H. preparation}

Potassium Hydroxide pellets were added in distilled water to prepare $10 \%$ solution in a clean glass tube and it was mixed well. A clean grease free glass slide was taken. Then a drop of the sample was put on it and freshly prepared $10 \%$ Potassium hydroxide (KOH) was added to it and after that sample was covered with grease free cover glass. Then it was allowed to react for 15-20 min to remove extra debris other than fungus. After that the cover glass was observed under high power (40X) lens and the findings were noted down properly [10].

\section{Grams stain test}

Clean grease free glass slide was taken to prepare dry equal thick preparation i.e. smear. Then the smear was fixed by passing 3-4 times over the flame of a Bunsen burner. This fixation kills the vegetative form of microbes, render them permeable to stain and make the material stick to the surface of the slide and prevent autolytic changes. Fixed prepared smear was covered with Gram's crystal violet solution and it was allowed to remain for mentioning time as per kit procedure. Then the smear was washed off with tap water to remove excessive reagent. Then smear was covered with Gram's Iodine solution and it was allowed to remain for some time. Again the smear was washed off with tap water to remove excessive reagent. The smear was decolorized with Gram's de-colourizer by holding the slide at slant position and pour Gram's decolourizeacetone from its upper end upto removal of colour of primary dye i.e Gram's Crystal Violet. Then the smear was washed off with tap water to remove excessive reagent. After that the smear was covered with Safranin solution and it was allowed to remain for mentioning time as per kit procedure. Then the smear was again washed off with tap water to remove excessive reagent. The smear was blotted and it was allowed to dry. Then the slide was examined under oil immersion lens and the findings were properly noted $[10,11]$.

\section{Culture study \\ Fungal culture method}

Respected materials were collected with a sterile cotton swab for inoculation purpose of selected fungal culture media (i.e. An artificial preparation).

In the clinical microbiology laboratory, culture method was employed in isolation of organisms (The streak culture method was routinely employed). Then appropriate selective solid media i. e Sabouraud Dextrose Agar Base (SDA), Modified (Dextrose Agar Base, Emmons) for inoculation purpose was selected. After that the selective solid media were dried in Hot air oven and the dried medium was allowed to cool before specimen inoculation. Selective samples were inoculated by sterile cotton swab to the surface of well dried culture media. After streaking process inoculated medium was incubated in inverted position at $37^{\circ} \mathrm{C}$ for 5-7 d. After incubation period growth was examined by naked eye in form of colony and the growth was confirmed by performing different related biochemical reactions and different staining procedures. After that Results were noted down properly [10].

\section{Aerobic culture method}

Respected materials collected with a sterile cotton swab for inoculation purpose on selected aerobic culture media (i.e. An artificial preparation). After that, in the clinical microbiology laboratory, culture method was employed in isolation of an organism (The streak culture method was routinely employed). Appropriate solid media, i.e. MacConkey Agar (MA) and Columbia Blood agar (BA) was selected for inoculation purpose. Then selective solid media were dried in hot air oven and dried medium was allowed to cool before specimen inoculation. Then the selected sample was inoculated on the surface of the cool dried medium with a sterile cotton swab to the surface of well dried culture media. After streaking process inoculated medium was incubated in inverted position at $37{ }^{\circ} \mathrm{C}$ for $24-48 \mathrm{~h}$ in the incubator under aerobic condition and $10 \%$ Carbon di-oxide $\left(\mathrm{CO}_{2}\right)$ atmospheric condition. After selecting incubation period, growth was examined by naked eye in form of colonization and growth was confirmed by performing different related biochemical reactions and different related staining procedures. After that the reports were isolated and noted down properly [10]. 


\section{RESULTS}

\section{Physical measurements}

Colour, odour, appearance and $\mathrm{pH}$ of all samples was assessed and presented properly in table $1,2,3,4$. The room temperature was found in the range of $30^{\circ} \mathrm{C}-33^{\circ} \mathrm{C}$ and the humidity was $27 \%-62 \%$.

\section{Colour}

Table 2 shows that at the time of collection all the samples were milky white in colour and it was found to change day by day. Fungal growth was observed on the $6^{\text {th }}$ day of collection in the case of $E$. antiquorum, E. caducifolia and E. tirucalli which leads to colour changes from milky white to greyish but in case of E. nivulia, fungal growth was not found upto the $7^{\text {th }}$ day of collection, hence, no colour changes were found in E. nivulia sample. It was also found that colour was unchanged up to $10^{\text {th }}$ days and more when the sample was stored in the refrigerator.

\section{Odour}

It was found that at the time of collection, very mild and characteristic odour was found in E. tirucalli sample, whereas slight pungent odour was found in case of rest of the samples. Table 3 shows that changes in odours were not found in E. nivulia sample upto $7^{\text {th }}$ day of collection, whereas slight pungent odour was found in E. tirucalli sample from the $3^{\text {rd }}$ day of collection upto $7^{\text {th }}$ day. Pungent smell was decreased after day five in case of $E$. antiquorum whereas pungent smell was found stronger from $4^{\text {th }}$ day of collection and onward than the $3^{\text {rd }}$ day of collection. It was also found that odour was unchanged up to $10^{\text {th }}$ days and more when sample was stored in the refrigerator.

Table 2: Colour of all samples at room temperature and refrigerated temperature

\begin{tabular}{|c|c|c|c|c|}
\hline \multicolumn{5}{|c|}{ Observation at room temperature } \\
\hline Days & Euphorbia antiquorum & Euphorbia caducifolia & Euphorbia nivulia & Euphorbia tirucalli \\
\hline 1 & Milky white & Milky white & Milky white & Milky white \\
\hline 2 & Same as D1 & Same as D1 & Same as D1 & Same as D1 \\
\hline 3 & Same as D2 & Same as D2 & Same as D2 & Same as D2 \\
\hline 4 & Liquid milky white and clot turns blackish & Same as D3 & Same as D3 & Liquid milky white and clot turns blackish \\
\hline 5 & Same as D4 & $\begin{array}{l}\text { Liquid milky white and } \\
\text { clot turns blackish }\end{array}$ & Same as D4 & Same as D4 \\
\hline 6 & Greyish colour with slight fungal growth & $\begin{array}{l}\text { Greyish colour with } \\
\text { slight fungal growth }\end{array}$ & Same as D5 & $\begin{array}{l}\text { Greyish colour with very slight fungal } \\
\text { growth }\end{array}$ \\
\hline 7 & $\begin{array}{l}\text { Greyish colour with prominent fungal } \\
\text { growth }\end{array}$ & $\begin{array}{l}\text { Greyish colour with } \\
\text { prominent fungal growth }\end{array}$ & Same as D6 & Greyish colour with slight fungal growth \\
\hline \multicolumn{5}{|c|}{ Observation at refrigerated temperature } \\
\hline $1-10$ & Milky white & y white & Milky white & Milky white \\
\hline
\end{tabular}

Table 3: Odour of all samples at room temperature and refrigerated temperature

\begin{tabular}{lllll}
\hline Observation at room temperature & & & \\
\hline Days & Euphorbia antiquorum & Euphorbia caducifolia & Euphorbia nivulia & Euphorbia tirucalli \\
\hline 1 & Slight pungent & Slight pungent & Slight pungent & Mild characteristic \\
2 & Slight pungent & Slight pungent & Same as D1 & Mild characteristic \\
3 & Slight pungent & Slight pungent & Same as D1 & Slight pungent \\
4 & Slight pungent & More pungent than D3 & Same as D1 & Slight pungent \\
5 & Slight pungent & Same as D4 & Same as D1 & Same as D4 \\
6 & Less pungent than D5 & Same as D4 & Same as D1 & Same as D4 \\
7 & Less pungent that D6 & Same as D4 & Same as D1 & Same as D4 \\
\hline Observation at refrigerated temperature & & & Mild characteristics \\
\hline $1-10$ & Slight pungent & Slight pungent & Slight pungent & \\
\hline
\end{tabular}

D-Day

\section{Appearances}

It was found that at the time of collection, some part of the latex was liquid and some part was clotted into lathery mass. Clotted part was found to increase on the next day, meanwhile liquid part was decreased. Clotting was found to increase day by day. It was found that E. antiquorum, E. caducifolia and E. nivulia latex was fully clotted at the $7^{\text {th }}$ day of collection, whereas some liquid part was still remained at the $7^{\text {th }}$ day of collection in case of E. tirucalli (table 4).

Table 4: Appearances of all samples at room temperature and refrigerated temperature

\begin{tabular}{lllll}
\hline Observation at room temperature & & & \\
\hline Day & Euphorbia antiquorum & Euphorbia caducifolia & Euphorbia nivulia & Euphorbia tirucalli \\
1 & Slight clotting & Slight clotting & Slight clotting & Very slight clotting \\
2 & Clotting increased than D1 & Clotting increased than D1 & Clotting increased than D1 & Clotting increased than D1 \\
3 & Same as D2 & Same as D2 & Clotting increased than D2 & Same as D2 \\
4 & Same as D3 & Same as D3 & Clotting increased than D3 & Same as D2 \\
5 & Clotting increased than D4 & Same as D2 & Clotting increased than D4 & Clotting increased than D4 \\
6 & Most of the part clotted & Clotting increased than D5 & Most of the part clotted & Same as D5 \\
7 & Fully clotted & Fully clotted & Fully clotted & Some liquid portion remain, mostly clotted \\
\hline Observation at refrigerated temperature & & \\
\hline $1-6$ & Liquid with slight clotting & Liquid with slight clotting & Liquid with slight clotting & Liquid with slight clotting \\
7 & Clotting slight increased & Clotting slight increased & Same as D6 & Same as D6 \\
$8-10$ & Same as D7 & Same as D7 & Same as D7 & Same as D7 \\
\hline
\end{tabular}




\section{pH}

It was found that all the sample possesses the acidic $\mathrm{pH}(4.25-$ 4.40 ), at the $1^{\text {st }}$ day of collection. It was found that the $\mathrm{pH}$ was increased day by day up to the $7^{\text {th }}$ day of collection. It was found that $\mathrm{pH}$ range was 4.25-5.18 in case of E. antiquorum, 4.79-5.12 in case of E. caducifolia, 4.48-4.76 in case of E. nivulia and 4.40-5.42 in case of E. tirucalli. It was also found that very slight changes was observed in case of refrigerated samples upto the $10^{\text {th }}$ day after collection (table 5).

Table 5: pH of all samples at room temperature and refrigerated temperature

\begin{tabular}{lllll}
\hline \multicolumn{2}{l}{ Observation at room temperature } & & \\
\hline Days & Euphorbia antiquorum & Euphorbia caducifolia & Euphorbia nivulia \\
\hline 1 & 4.25 & 4.79 & 4.48 & 4.48 \\
2 & 4.25 & 4.80 & 4.50 & 4.40 \\
3 & 4.27 & 4.80 & 4.62 & 4.45 \\
4 & 5.18 & 4.93 & 4.76 & 5.25 \\
5 & 5.18 & 5.05 & Clotted & 5.25 \\
6 & Clotted & 5.12 & Clotted & 5.40 \\
7 & Clotted & Clotted & & \\
\hline Observation at refrigerated temperature & & $4.92-4.98$ \\
\hline $1-10$ & $5.12-5.21$ & $4.84-4.90$ & \\
\hline
\end{tabular}

\section{Microbiological measurements}

Table 6 shows that, at room temperature, E. nivulia latex sample was free of microbial growth upto the $7^{\text {th }}$ day of incubation at $37^{\circ} \mathrm{C}$ after collection. It was found that E. antiquorum and E. caducifolia latex sample was free of microbial growth upto $6^{\text {th }}$ day after collection but Aspergillus niger was seen in fungal culture and structure resembling fungal filaments was seen in 10\% Potassium hydroxide $(\mathrm{KOH})$ preparation on the $7^{\text {th }}$ day of the same sample. E. tirucalli latex sample was free of microbial growth upto $6^{\text {th }}$ day after collection but candida albicans was seen in fungal culture and structure resembling a filamentous fungus (Dimorphic yeast) was seen in $10 \%$ Potassium hydroxide $(\mathrm{KOH})$ preparation on the $7^{\text {th }}$ day sample.

Table 6: Microbial assessment of all latex samples at room temperature

\begin{tabular}{|c|c|c|c|c|c|}
\hline \multirow[b]{2}{*}{ Samples } & \multirow[b]{2}{*}{ Days } & \multicolumn{4}{|c|}{ Observation of sample (At room temperature) } \\
\hline & & Gram's stain & Aerobic culture & $10 \% \mathrm{KOH}$ preparation & Fungal culture \\
\hline \multirow[t]{2}{*}{$\begin{array}{l}\text { Euphorbia } \\
\text { antiquorum }\end{array}$} & Day 1-day 6 & $\begin{array}{l}\text { Microorganism not } \\
\text { seen }\end{array}$ & $\begin{array}{l}\text { No organism } \\
\text { isolated }\end{array}$ & Fungal filament not seen & $\begin{array}{l}\text { No fungal pathogen } \\
\text { isolated }\end{array}$ \\
\hline & Day 7 & $\begin{array}{l}\text { Microorganism not } \\
\text { seen }\end{array}$ & $\begin{array}{l}\text { No organism } \\
\text { isolated }\end{array}$ & $\begin{array}{l}\text { Structure resembling fungal } \\
\text { filaments seen }\end{array}$ & Aspergillus niger seen \\
\hline \multirow[t]{2}{*}{$\begin{array}{l}\text { Euphorbia } \\
\text { caducifolia }\end{array}$} & Day 1-day 6 & $\begin{array}{l}\text { Microorganism not } \\
\text { seen }\end{array}$ & $\begin{array}{l}\text { No organism } \\
\text { isolated }\end{array}$ & Fungal filament not seen & $\begin{array}{l}\text { No fungal pathogen } \\
\text { isolated }\end{array}$ \\
\hline & Day 7 & $\begin{array}{l}\text { Microorganism not } \\
\text { seen }\end{array}$ & $\begin{array}{l}\text { No organism } \\
\text { isolated }\end{array}$ & $\begin{array}{l}\text { Structure resembling fungal } \\
\text { filaments seen }\end{array}$ & Aspergillus niger seen \\
\hline Euphorbia nivulia & Day 1-day 7 & $\begin{array}{l}\text { Microorganism not } \\
\text { seen }\end{array}$ & $\begin{array}{l}\text { No organism } \\
\text { isolated }\end{array}$ & Fungal filament not seen & $\begin{array}{l}\text { No fungal pathogen } \\
\text { isolated }\end{array}$ \\
\hline \multirow[t]{2}{*}{$\begin{array}{l}\text { Euphorbia } \\
\text { tirucalli }\end{array}$} & Day 1-day 6 & $\begin{array}{l}\text { Microorganism not } \\
\text { seen }\end{array}$ & $\begin{array}{l}\text { No organism } \\
\text { isolated }\end{array}$ & Fungal filament not seen & $\begin{array}{l}\text { No fungal pathogen } \\
\text { isolated }\end{array}$ \\
\hline & Day 7 & $\begin{array}{l}\text { Microorganism not } \\
\text { seen }\end{array}$ & $\begin{array}{l}\text { No organism } \\
\text { isolated }\end{array}$ & $\begin{array}{l}\text { Structure resembling filamentous } \\
\text { fungus (Dimorphic yeast) seen }\end{array}$ & Candida albicans seen \\
\hline
\end{tabular}

Table 7 shows that at refrigerated temperature, smear examination and culture study showed negative results which denotes that all the samples was free of microbial growth upto the $10^{\text {th }}$ day after collection of sample.

Table 7: Microbial assessment of all latex samples at refrigerated temperature

\begin{tabular}{|c|c|c|c|c|c|}
\hline \multicolumn{6}{|c|}{ Observation of sample (Refrigerated) } \\
\hline Samples & Days & Gram's stain & Aerobic culture & $10 \% \mathrm{KOH}$ preparation & Fungal culture \\
\hline $\begin{array}{l}\text { Euphorbia } \\
\text { antiquorum }\end{array}$ & Day 1-Day 10 & Microorganism not seen & No organism isolated & $\begin{array}{l}\text { Fungal filament not } \\
\text { seen }\end{array}$ & $\begin{array}{l}\text { No fungal pathogen } \\
\text { isolated }\end{array}$ \\
\hline Euphorbia tirucalli & Day 1-Day 10 & Microorganism not seen & No organism isolated & $\begin{array}{l}\text { Fungal filament not } \\
\text { seen }\end{array}$ & $\begin{array}{l}\text { No fungal pathogen } \\
\text { isolated }\end{array}$ \\
\hline $\begin{array}{l}\text { Euphorbia } \\
\text { caducifolia }\end{array}$ & Day 1-Day 10 & Microorganism not seen & No organism isolated & $\begin{array}{l}\text { Fungal filament not } \\
\text { seen }\end{array}$ & $\begin{array}{l}\text { No fungal pathogen } \\
\text { isolated }\end{array}$ \\
\hline Euphorbia nivulia & Day 1-Day 10 & Microorganism not seen & No organism isolated & $\begin{array}{l}\text { Fungal filament not } \\
\text { seen }\end{array}$ & $\begin{array}{l}\text { No fungal pathogen } \\
\text { isolated }\end{array}$ \\
\hline
\end{tabular}

\section{DISCUSSION}

Shelf-life is the length of time that a commodity may be stored without becoming unfit for use, consumption or sale. Shelf life depends on the degradation mechanism of the specific product. Most can be influenced by several factors: exposure to light, heat, and moisture, transmission of gases, mechanical stresses and contamination by things such as micro-organisms [6].

Snuhi latex has been used in the management of different disease condition. One of the important use of snuhi kshira (latex) is in ksharasutra (a medicated thread used in Ayurveda). The threads are 
prepared with surgical linen size, 20 by repeatedly smearing it with the latex of snuhi and a combination of certain vegetable caustics grown on a large scale in India and other parts of southern Asia known as ksharasutra (a medicated thread used in Ayurveda).

There are different species of Euphorbia available in India which are known as different varieties of snuhi. Geographical variation of all the species and its availability is the main problem for the collection of the snuhi latex. Hence it is necessary to know the shelf-life of these latex samples to know the maximum time for using the samples as these samples can transport from its available place.

The present study was carried out for seven to ten days to assess the shelf-life of all latex samples. Physical property like colour, odour, appearance, $\mathrm{pH}$ variation are the important factors to know the shelflife of samples. The result showed that in case of E. antiquorum, $E$. caducifolia and E. tirucalli, fungal growth was observed clearly in visual observation at room temperature on the $6^{\text {th }}$ day after collection, whereas no fungal growth was observed at refrigerated temperature upto the $10^{\text {th }}$ day after collection of the same samples. It was also found that the latex was fully clotted in case of E. antiquorum, $E$. caducifolia and E. nivulia, at room temperature, whereas the appearance was unchanged at refrigerated temperature, highlights the effect of $\mathrm{pH}$ and temperature on the enzymes which is responsible for the clotting activity of the latex protein [4].

The result showed that at room temperature microbial growth was found at day $7^{\text {th }}$ in case of Euphorbia antiquorum, Euphorbia caducifolia and Euphorbia tirucalli latex whereas in case of and Euphorbia nivulia latex no microbial growth was found upto the $7^{\text {th }}$ days. On the other hand, all the refrigerated samples were free from microbial growth $10^{\text {th }}$ day.

\section{CONCLUSION}

From the present study, it can be concluded that factors like temperature and, moisture are highly responsible for sample degradation. Data specified in the present study indicates that Euphorbia nivulia latex has maximum stability (7days) in comparison to the Euphorbia antiquorum, Euphorbia caducifolia and Euphorbia tirucalli latex ( $6 \mathrm{~d})$. At refrigerated temperatures at $4-5^{\circ} \mathrm{C}$, stability is maintained up to $10 \mathrm{~d}$.

\section{ACKNOWLEDGEMENT}

Authors would like to thanks National Medicinal Plant Board, Ministry of AYUSH, New Delhi for the financial help under the research project. Authors are also indebted to the IPGT and RA,
Gujarat Ayurved University for giving the facility to conduct the whole research work.

\section{FINANCIAL SUPPORT AND SPONSORSHIP}

The work was supported by National Medicinal Plant Board, Ministry of AYUSH, New Delhi.

\section{AUTHORS CONTRIBUTIONS}

The first and three authors have designed the concept and all the authors have contributed in conducting the experimental studies, data analysis and manuscript preparation.

\section{CONFLICT OF INTERESTS}

Nil

\section{REFERNCES}

1. Bhavamishra. Bhavaprakasha samhita, Shashrina BM. Editor. Varanasi: Chaukhamba Sanskrit Bhawan; 2013. p. 854 .

2. Nishteswar K, Hemadri K. Dravyagunavijnana. $1^{\text {st }}$ ed. Delhi: Chaukhambha Sanskrit Pratisthan; 2010. p. 294-6.

3. Bhavmishra. Guduchyadi Varga, 67-72. In: Chunekar KC. (Ed), Bhavaprakash nighantu. 1st ed. Varanasi: Chaukhambha Bharati Academy; 2010. p. 289-92.

4. Sharma T, Dash P, Das D, Ghosh G. Kinetic and thermodyanamic studies of purified protein isolated from Euphorbia tirucalli latex. Asian J Pharm Cin Res 2014;7:275-8.

5. Bajaj S, Singla D, Sakhuja N. Stability testing of pharmaceutical product. J Appl Pharm Sci 2012;2:129-38.

6. Phimolsiripol Y, Suppakul P. Techniques in shelf life evaluation of food products. In: Reference module in food sciences. Elsevier: Academic Press; 2016. p. 1-8.

7. Kilcast D, Subramaniam P. The stability and shelf-life of food, Cambridge, England: Woodhead Publishing limited; 2000. p. $1-15$.

8. Saxena HO, Brahmam M. Flora of orisha. Vol. 3. Bhubaneswar: Orissa Forest Development Corporation Ltd; 1995. p. 1632-4.

9. Prakash EJJ. A text book of plant anatomy. $1^{\text {st }}$ edition. Delhi: Emkay publication; 1987. p. 225.

10. Alfred EB. Benson: Microbiological Application. 8th Edition. The McGraw-Hill Companies; 2001. p. 64.

11. Microbiologyinfo.com. Available from: https://microbiologyinfo.com/gram-staining-principle-procedure-interpretationexamples-and-animation/ [Last accessed on 12 Jun 2018]. 